\title{
Impact of Self-Efficacy on Psychological Well-Being among Undergraduate Students
}

\author{
Shamsul Siddiqui ${ }^{1}$
}

\section{ABSTRACT:}

The present investigation was carried out to study the impact of Self-efficacy on Psychological Well-being among undergraduate students. The sample consisted of 100 (50 Male and 50 Female) students selected from the Aligarh Muslim University, Aligarh. In order to collect the requisite data, General Self-Efficacy Scale (S. Sud, Schwarzer and Jerusalum, 1995) and Psychological Well-being (Carol Ryff, 1989) was used to study the mentioned problem Simple Linear Regression was used analysis impact the self efficacy on psychological well being among undergraduate students. The findings of the present study show that, correlation between Selfefficacy and Psychological Well-being among Male students was found $\mathrm{R}=.596$ and actual contribution of predictor variable to criterion variable was found to be $35.6 \%$ whereas among Female students correlation between Self-efficacy and Psychological Well-being was found $\mathrm{R}=$ .551 and actual contribution of predictor variable to criterion variable was found to be $30.4 \%$. Further t-test was applied between Self-efficacy as well as Psychological Well-being of both groups, where it was found that there was insignificant difference between Self-efficacy of Male and Female students but a significant difference was found between Psychological well-being of both groups.

Keywords: Self-efficacy, Psychological well-being

The concept of Albert Bandura's self-efficacy which relates to judgment people make concerning their ability to execute behavior relevant to a specific task or situations. It refers to the confidence in once ability to behave in such a way or to produce a desirable outcome (Bandura, 1977). Self efficacy makes a difference in how people feel, think and act. Selfefficacy pertains to optimistic belief about being able to cope with a variety of stressors. Selfefficacy is defined as self-evaluation of one's competence to successfully execute a course of action necessary to reach desired outcome. It is a multidimensional construct that varies according to the domain of demands (Zimmerman, 2000), and therefore it must be evaluated at a level that is specific to the outcome domain (Bandura, 1986). Self-efficacy pertains to optimistic belief about being able to cope with a variety of stressors. People with high self efficacy choose to perform more challenging and difficult task. In terms of feeling low level of self efficacy is concerned with depression, anxiety and helplessness.

\footnotetext{
${ }^{1}$ Research Scholar, Department of Psychology, Aligarh Muslim University, Aligarh
} 
People with high level of self-efficacy approach life with a can - do attitude that allows them to see challenges as problems to be solved instead of threats that must be avoided. They also set appropriately challenging goal for themselves and maintain a strong commitment to those goals. People with strong self-efficacy enjoy life because they are highly engaged. When they encounter stressful situations their belief in their ability to manage situations to their benefit allows being self confident.

High self- efficacy is related to positive well-being, regulation of stress, higher self-esteem, better physical condition, better adaptation to and recovery from diseases (Bandura, 1997; Bisschop, Knegsman, Beekman, \& Deeg, 2004; Kuijer \& de Ridder, 2003). On the other hand, low self-efficacy is related to more symptoms of anxiety and depression (Faure \& Loxton, 2003; Kashdan \& Roberts, 2004; Shnek, Irvine, Stewart, \& Abbey, 2001), as well as to lower levels of subjective well-being (Barlow, Wright, \& Cullen, 2002; Bandura, Caprara, Barbaranelli, Gerbino, \& Pastorelli, 2003; Caprara, 2002).

Self-efficacy has been found to be linked with academic achievement and performance (Salami \& Ogundokun, 2009) and is highly contextualized (Bandura, 1997): for this reason, it appeared necessary to study different aspects of its effects in each period of human development and psychological well-being from infancy to adulthood. In terms of self-efficacy gender is an important aspect for investigation; generally males are considered to be superior and females as inferior commonly in our culture. Social cognitive theory has been especially important in understanding social influence on gender (Bugental \& Grusec, 2006). The females have to bear the discrimination of the majority in every sphere starting from their own family to the society who provide impoverished environment, as a result affect their well-being and overall personality (Bussey \& Bandura, 1999). The discrimination and differentiation on the basis of gender is leading to inferiority complexes among the females in both joint as well as nuclear families. In a study conducted by Dona, Scholz, Schwarzer and Sud (2002) have reported the superiority of males with regard to self-efficacy as compared to females in various cultures.

\section{PSYCHOLOGICAL WELL-BEING}

Psychological wellbeing is a subjective feeling of containment happiness satisfaction with life experiences ones role in the world of work, sense of achievement, utility ,belongingness, and no distress , sections or worry etc. (Shek, 1997; Sastre \& Ferriere, 2000; VanWel, Linssen \& Abma, 2000) showed that various factors affect adolescent's level of psychological well-being. psychological well being is a somewhat malleable concept which is the feeling of people everyday life activities such feelings may range negative mental state or psychological strains such as anxiety, expression, frustration ,emotional exhaustion , unhappiness, dissatisfaction to a state which has been identified as positive mental health (Jahoda ,1958). Bornstein, Davidson, Keyes, and Moore (2003) defined well-being as "the state of successful performance throughout the life course integrating psychical, cognitive, and socio-emotional functions that results in 
productive activities deemed significant by one's cultural community, fulfilling social relationships, and the ability to transcend moderate psychosocial and environmental problems". This construct was articulated in subjective (SWB) and psychological well-being (PWB).

The first type of well-being is in agreement with the hedonic perspective (Watson, Clark, \& Tellegen, 1988; Diener et al., 1999) and includes the dimensions linked to physical health, positive and negative effect, and life satisfaction, while the second one is consistent with the eudaimonic perspective (Ryff, 1989; Ryff \& Singer, 1996; Kashdan, Biswas-Diener, \& King, 2008) and includes the dimensions of self-actualization, personal development, and relations with environment. The psychological well-being has been considered by Ryff (1989) as a set of psychological characteristics implicated in positive human functioning (Keyes, Ryff, \& Schmotkin, 2002): autonomy, environmental mastery, self acceptance, purpose in life, positive relations with others, and personal growth. The six dimensions of PWB evoke different challenges that people encounter as they try to function positively (Ryff \& Keyes, 1995). Individuals attempt to feel good even when aware of their own limitations (self-acceptance), seek to develop and maintain warm and trust in interpersonal relationships (positive relations with others), try to manage their environment so as to meet personal needs and desires (environmental mastery); in addition, individuals look for a sense self-determination and personal authority (autonomy), finding meaning in one's efforts and challenges (purpose in life); lastly, individuals tend to seek their talents and capacities (personal growth). Several studies have documented the effects of socio demographic variables such as age and sex in the dimensions of PWB (Clarke et al., 2000; Keyes \& Ryff, 1998; Marmot et al., 1998; Ryff \& Singer, 1996). By Ryff (1989), environmental mastery and autonomy tended to increase with age (especially from young to midlife adults), while purpose in life and personal growth decreased with age (especially from midlife to old aged adults), without age differences for self-acceptance and positive relations with others; furthermore, Ryff and Singer (1996) pointed out that women of all ages valued themselves higher on positive relations with others and personal growth. Recently, in Italian context, Sagone and De Caroli (in press) found that late adolescents showed greater personal growth and purpose in life than middle ones and boys valued themselves higher on environmental mastery and self-acceptance than girls.

Psychological well-being and self-efficacy have been shown to predict students' scholastic performance and success. As reported by some researches, students who expressed high levels of self-efficacy and well-being were motivated to participate in relevant academic activities and to develop positive attitudes that led to success at school (Ozer \& Bandura, 1990; Lyubomirsky, 2001; Khramtsova et al., 2007) and were likely to perform well in their academic goals (Zimmerman, Bandura, \& Martinez-Pons, 1992). Furthermore, students who perceived themselves as highly efficient in school context were likely to develop positive attitudes toward the learning of subjects. Students with high psychological well-being and life satisfaction were found to be more flexible, resilient, and efficient in problem solving and were more committed to 
their academic goals and pursued success rather than to be focused on avoiding of their failures (Pajares \& Schunk, 2001).

\section{OBJECTIVES OF THE STUDY}

1. To study the impact of self-efficacy on psychological well being on undergraduate male and female students.

2. To study the relationship between self-efficacy and psychological well being of undergraduate male and female students.

3. To study the difference between self-efficacy as well as psychological well being of undergraduate male and female students.

\section{HYPOTHESES OF THE STUDY}

1. There will be significant impact of self-efficacy on psychological well being on undergraduate male and female students.

2. There will be positive relationship between self-efficacy and different dimensions of psychological well being of undergraduate male and female students.

3. There will be significant difference between self-efficacy as well as psychological well being of undergraduate male and female students.

\section{METHODOLOGY}

\section{Sample}

The sample of the present study consisted of 100 (50 male \& 50 females) students. Purposive sampling technique used from the Aligarh Muslim University Aligarh.

\section{Tools}

\section{General Self-Efficacy Scale}

(GSES; S. Sud, R. Schwarzer \& M. Jerusalem, 1995): the general self- efficacy scale is a 10 items psychometrics scale that is design to assess optimistic self-belief to cope with a variety of difficult demand in life. the scale has been originally developed in Germany by Matthias Jerusalem and Ralf Schwarzer in 1981, first as a 20-item version and later as a reduced 10-item version by Sud, R. Schwarzer along and M. Jerusalem (1995), and the test is self- evaluation questionnaire consisting of 10 statement related to situation. Cronbach`s alpha ranged from 0.76 to 0.90 , with the majority in the high 0.80 . It is a 4 point likert scale ranging from not at all true to exactly true. Total score ranged from 10 to 40 points.

\section{Psychological well being scales (PWB):}

In the present investigation, psychological well being was measured by Ryff 's scales of psychological well being scale developed by Carol Ryff (1989). The scale consists of 54 items. Which consists a series of statement reflecting the six areas of psychological well being: selfacceptance, positive relation with others, autonomy, environmental mastery, purpose in life and personal growth? Respondents rate statement on a scale of 1 to 6 , with 1 indicating strong 
disagreement and 6 indicating strong agreement. The internal consistency coefficients of the scale between 0.86 and 0.93 .

\section{PROCEDURE}

The scales were administered on the Under Graduate students, before distributing the respective tools good rapport was established and proper instructions were given to the participants and also ensured for confidentiality; after that questionnaires were given, participants were taken half an hour to give their complete responses on the measures and then the data were collected.

\section{Statistical Analysis}

To verify the research objectives data was analyzed, Simple Linear Regression and t-test analyses were applied.

\section{RESULTS}

Table-1: Represents Simple Linear Regression analysis, Self-Efficacy as predictor of Psychological Well-being among Undergraduate Male Students.

\section{Model Summary}

\begin{tabular}{|l|r|r|r|r|}
\hline Model & \multicolumn{1}{|c|}{$\mathrm{R}$} & R Square & \multicolumn{1}{c|}{$\begin{array}{c}\text { Adjusted R } \\
\text { Square }\end{array}$} & $\begin{array}{l}\text { Change Statistics R } \\
\text { Square Change }\end{array}$ \\
\hline 1 & $.596^{\mathrm{a}}$ & .356 & .349 & .356 \\
\hline
\end{tabular}

a. Predictors: (Constant), Self-Efficacy Male

The above table represents the Model Summary indicating one Predictor (Self-efficacy) of the model, where correlation between Self-efficacy and Psychological Well-being among male students was found to be $\mathrm{R}=.596$, further $\mathrm{R}$ Square Change $=.356$ which represents the actual contribution of Self-efficacy to Psychological Well-being, the real covariance magnitude of Predictor variable: Self-efficacy which contribute to the Criterion Variable: Psychological Wellbeing came out as $35.6 \%$. 
Table-2: Showing the Coefficient details of Self-Efficacy and Psychological Well-being among Undergraduate Male Students.

\section{Coefficients $^{\mathrm{a}}$}

\begin{tabular}{|c|c|c|c|c|c|c|}
\hline \multirow{2}{*}{\multicolumn{2}{|c|}{ Model }} & \multicolumn{2}{|c|}{$\begin{array}{c}\text { Unstandardized } \\
\text { Coefficients }\end{array}$} & \multirow{2}{*}{$\begin{array}{c}\begin{array}{c}\text { Standardized } \\
\text { Coefficients }\end{array} \\
\text { Beta }\end{array}$} & \multirow[b]{2}{*}{ [ } & \multirow[b]{2}{*}{ Sig. } \\
\hline & & B & Std. Error & & & \\
\hline 1 & (Constant) & 151.004 & 10.127 & & 14.911 & .000 \\
\hline & $\begin{array}{l}\text { Self-Efficacy } \\
\text { Male }\end{array}$ & 2.325 & .316 & .596 & 7.357 & .000 \\
\hline
\end{tabular}

a. Dependent Variable: Overall Psychological Well-being Male

Table-2 (Coefficient) indicates that Self-efficacy (Predictor) influences Psychological Wellbeing (Criterion). The Statistical value given in the mentioned table indicates that $\mathrm{t}=7.357$ values are significant for Self-efficacy and also show the positive relationship between Selfefficacy and Psychological Well-being.

The Value of Beta is $r=.596$ which indicates that Self-efficacy significantly influences degree of Psychological Well-being among Undergraduate Male Students. The relationships between these two variables represent linear correlation among male students; it means that when Self-efficacy Increases Psychological Well-being also increases and when Self-efficacy decreases then Psychological Well-being also decreases.

Table-3: Represents the Correlations between Self-Efficacy and Different dimensions of Psychological Well-being among Male.

\section{Correlations}

\begin{tabular}{|l|r|r|r|r|r|r|}
\hline & \multicolumn{1}{|c|}{$\begin{array}{c}\text { Self } \\
\text { Acceptance } \\
\text { Male }\end{array}$} & $\begin{array}{c}\text { Positive } \\
\text { Relation } \\
\text { Male }\end{array}$ & $\begin{array}{c}\text { Autonomy } \\
\text { Male }\end{array}$ & $\begin{array}{c}\text { Environment } \\
\text { al Mastery } \\
\text { Male }\end{array}$ & $\begin{array}{c}\text { Purpose in } \\
\text { Life Male }\end{array}$ & $\begin{array}{c}\text { Personal } \\
\text { Growth } \\
\text { Male }\end{array}$ \\
\hline $\begin{array}{l}\text { Self-Efficacy } \\
\text { Male }\end{array}$ & $.395^{* *}$ & $.422^{* *}$ & $.621^{* *}$ & $.612^{* *}$ & $.526^{* *}$ & $.408^{* * *}$ \\
$\begin{array}{l}\text { Pearson } \\
\text { Correlation }\end{array}$ & $\mathrm{N}$ & 100 & 100 & 100 & & \\
\end{tabular}

**. Correlation is significant at the 0.01 level (2-tailed). 
The above table indicates that Self-efficacy of male undergraduate students significantly correlated with different dimensions of Psychological well-being i.e. Self Acceptance, Positive Relation, Autonomy, Environmental Mastery, Purpose in Life, Personal Growth respectively.

Table-4: Represents Simple Linear Regression analysis, Self-Efficacy as predictor of Psychological Well-being among Undergraduate Female Students.

\section{Model Summary}

\begin{tabular}{|l|r|r|r|r|}
\hline Model & \multicolumn{1}{|c|}{$\mathrm{R}$} & R Square & $\begin{array}{c}\text { Adjusted R } \\
\text { Square }\end{array}$ & $\begin{array}{l}\text { Change Statistics } \\
\text { R Square Change }\end{array}$ \\
\hline 1 & $.551^{\mathrm{a}}$ & .304 & .297 & .304 \\
\hline
\end{tabular}

a. Predictors: (Constant), Self-Efficacy Female

The above table represents the Model Summary indicating one Predictor (Self-efficacy) of the model, where correlation between Self-efficacy and Psychological Well-being among female students was found to be $\mathrm{R}=.551$, further $\mathrm{R}$ Square Change $=.304$ which represents the actual contribution of Self-efficacy to Psychological Well-being, the real covariance magnitude of Predictor variable: Self-efficacy which contribute to the Criterion Variable: Psychological Wellbeing came out as $30.4 \%$.

Table-5: Showing the Coefficient details of Self-Efficacy and Psychological Well-being among Undergraduate Female Students.

\section{Coefficients $^{\mathrm{a}}$}

\begin{tabular}{|c|c|c|c|c|c|c|}
\hline \multirow{2}{*}{\multicolumn{2}{|c|}{ Model }} & \multicolumn{2}{|c|}{$\begin{array}{c}\text { Unstandardized } \\
\text { Coefficients }\end{array}$} & \multirow{2}{*}{\begin{tabular}{|c|}
$\begin{array}{c}\text { Standardized } \\
\text { Coefficients }\end{array}$ \\
Beta \\
\end{tabular}} & \multirow[b]{2}{*}{$\mathrm{t}$} & \multirow[b]{2}{*}{ Sig. } \\
\hline & & B & Std. Error & & & \\
\hline 1 & (Constant) & 124.268 & 14.196 & & 8.754 & .000 \\
\hline & $\begin{array}{l}\text { Self-Efficacy } \\
\text { Female }\end{array}$ & 2.978 & .455 & .551 & 6.543 & .000 \\
\hline
\end{tabular}

a. Dependent Variable: Overall Psychological Well-being Female

Table-5 indicates that Self-efficacy (Predictor) influences Psychological Well-being (Criterion). The Statistical value given in the mentioned table indicates that $t=6.543$ values are significant for Self-efficacy and also show the positive relationship between Self-efficacy and Psychological Well-being.

The Value of Beta is $r=.551$ which indicates that Self-efficacy significantly influences degree of Psychological Well-being among Undergraduate Male Students. The relationships between these 
two variables represent linear correlation among female students; it means that when Selfefficacy increases Psychological Well-being also increases and when Self-efficacy decreases then Psychological Well-being also decreases.

Table-6: Represents the Correlations between Self-Efficacy and Different dimensions of Psychological Well-being among Female.

\section{Correlations}

\begin{tabular}{|l|r|r|r|r|r|r|}
\hline & \multicolumn{1}{|c|}{$\begin{array}{c}\text { Self } \\
\text { Acceptance } \\
\text { Female }\end{array}$} & $\begin{array}{c}\text { Positive } \\
\text { Relation } \\
\text { Female }\end{array}$ & $\begin{array}{c}\text { Autonomy } \\
\text { Female }\end{array}$ & $\begin{array}{c}\text { Environmental } \\
\text { Mastery } \\
\text { Female }\end{array}$ & $\begin{array}{c}\text { Purpose in } \\
\text { Life Female }\end{array}$ & $\begin{array}{c}\text { Personal } \\
\text { Growth Female }\end{array}$ \\
\hline $\begin{array}{l}\text { Self-Efficacy } \\
\text { Female }\end{array}$ & .092 & $.207^{*}$ & $.447^{* *}$ & $.661^{* *}$ & $.240^{*}$ & .081 \\
Pearson Correlation & $\mathrm{N}$ & 100 & 100 & 100 & 100 & 100 \\
\hline
\end{tabular}

*. Correlation is significant at the 0.05 level (2-tailed).

**. Correlation is significant at the 0.01 level $(2-$ tailed).

The above table indicates that Self-efficacy of female undergraduate students significantly correlated with the dimensions of Psychological well-being i.e. Positive Relation, Autonomy, Environmental Mastery, and Purpose in Life while Self Acceptance and Personal Growth were insignificantly correlated.

Table-7: Represents the mean difference of Self-efficacy between male and female undergraduate students.

\begin{tabular}{|l|c|c|c|c|c|c|}
\hline \multicolumn{1}{|c|}{ Group } & N & Mean & SD & SED $_{\text {ED }}$ & t-value & Sig. \\
\hline $\begin{array}{l}\text { Self-Efficacy } \\
\text { Male }\end{array}$ & 100 & 31.20 & 7.335 & & & \\
\cline { 1 - 5 } $\begin{array}{l}\text { Self-Efficacy } \\
\text { Female }\end{array}$ & 100 & 31.00 & 3.423 & .809 & .24 & \\
\hline
\end{tabular}

Above table shows mean, SD and t-value of male and female undergraduate students respectively which indicates that there is insignificant difference of self efficacy among male and female undergraduate students. 
Impact of Self-Efficacy on Psychological Well-Being among Undergraduate Students

Table-8: Represents the mean difference of Psychological Wellbeing between male and female undergraduate students.

\begin{tabular}{|l|c|c|c|c|c|c|}
\hline \multicolumn{7}{|c|}{ PSYCHOLOGICAL WELL-BEING } \\
\hline \multicolumn{1}{|c|}{ Group } & N & Mean & SD & SED $_{\text {ED }}$ & t-value & Sig. \\
\hline $\begin{array}{l}\text { Psychological Well- } \\
\text { being Male }\end{array}$ & 100 & 223.55 & 28.592 & & & \\
\cline { 1 - 5 } $\begin{array}{l}\text { Psychological Well- } \\
\text { being Female }\end{array}$ & 100 & 216.60 & 18.489 & 3.404 & $2.217^{*}$ & 0.05 \\
\hline
\end{tabular}

Whereas, above table shows mean, SD and t-value of male and female undergraduate students which revealed that psychological well-being of Male and female undergraduate students has a significant difference at 0.05 level of significance.

\section{DISCUSSION}

It was found that there was a significant influence of Self-efficacy on Psychological Well-being among Male and female undergraduate Graduate students, which can be seen by the contribution of Predictor variable to Criterion variable as mentioned in the Table-1 (35.6\%) and Table-4 (30.4\%) respectively. This finding is supported by a number of studies; Bandura (1977) attributes the development of self-efficacy to four forces: mastery, social learning, social persuasion, and emotional and physical states. Of the four, the most powerful for producing selfefficacy is mastery and the most powerful is undermining self-efficacy is social persuasion. A number of structural conditions impact self-efficacy: social class, race, level of educations rural and urban backgrounds and gender all affect an individual global self-efficacy (Birch, 1987). Family structure to have a direct relationship to adolescent's self-efficacy (Bandura, 1995); Schneewind, 1995).

The second finding of the study also shows a significant relationship between self-efficacy and most of the dimensions of psychological well-being among Male and Female undergraduate Students. The psychological well-being has been considered by Ryff (1989) as a set of psychological characteristics implicated in positive human functioning (Keyes, Ryff, \& Schmotkin, 2002): autonomy, environmental mastery, self acceptance, purpose in life, positive relations with others, and personal growth. Ryff \& Keyes, (1995) reported that the six dimensions of PWB evoke different challenges that people encounter as they try to function positively. Individuals attempt to feel good even when aware of their own limitations for selfacceptance, seek to develop and maintain warm and trust in interpersonal relationships which shows the positive relations with others, and try to manage their environment so as to meet personal needs and desires which indicates environmental mastery; in addition, for the autonomy individuals look for a sense self-determination and personal authority, finding meaning in one's efforts and challenges shows purpose in life; lastly, for personal growth individuals tend to seek 
their talents and capacities. Several studies have documented the effects of socio demographic variables such as age and sex in the dimensions of Psychological Well Being (Clarke et al., 2000; Keyes \& Ryff, 1998; Marmot et al., 1998; Ryff \& Singer, 1996). The Third finding of the study showed an insignificant difference between Self-efficacy of undergraduate male and female students but Psychological Well-being significantly different among Male and Female undergraduate students.

\section{CONCLUSION}

On the basis of these finding it can be concluded that self-efficacy has its positive and significant impact on psychological Well-being among undergraduate students and it was also found that self-efficacy enhance the psychological well-being. Consequently, high level of self-efficacy Contributes to high levels of engagements and life satisfaction, if self-efficacy is low psychological well being also low, if self efficacy is high psychological well being also high.

\section{ACKNOWLEDGEMENTS}

I wish to compensate heartfelt thanks to Dr. Kr Sajid Ali Khan, Associate Professor, Department of Psychology, Aligarh Muslim University, Aligarh for his regular guidance. I also express my thanks to all participants in the study, my colleagues and friends who help me in this portion of research.

\section{REFERENCES}

1. Bandura, A., Adams, N.E., \& Beyer, J. (1977). Cognitive processing mediating Behavioral change. Journal of personality and social Psychology, 35, 124-139

2. Bandura, A. (1986). Social foundations of thought and action: A social cognitive theory. Englewood Cliffs, NJ: Prentice-Hall.

3. Bandura, A. (1997). Self-efficacy: the Exercise of Control. Freeman: New York.

4. Bandura, A., Caprara, G. V., Barbaranelli, C., Gerbino, M. \& Pastorelli, C. (2003). Role of affective self-regulatory efficacy on diverse spheres of psychosocial functioning. Child Development, 74, 769-782.

5. Barlow, J., Wright, C. \& Cullen, L. (2002). A job-seeking self-efficacy scale for people with physical disabilities: preliminary development and psychometric testing. British Journal of Guidance and Counselling, 30, 37-53.

6. Bisschop, M. I., Knegsman, D. M. W., Beekman, A. T. F. \& Deeg, D. J. H. (2004). Chronic diseases and depression: the modifying role of psychosocial resources. Social Science and Medicine, 59, 721-733.

7. Bornstein, M.H., Davidson, L., Keyes, C.L.M., \& Moore, K.A. (2003). Well-Being: Positive Development across the Life Course. Mahwah, NJ: Lawrence Erlbaum Associate.

8. Bugental, D.B., \& Grusec, J.E. (2006). Socialization processes. In W. Damon \& R. Lerner (Eds.), Handbook of child psychology (6th ed.). New York: Wiley. 
9. Bussey, K., \& Bandura, A., (1999). Social Cognitive Theory of gender development and differentiations. Psychological Review, 106, 676-713.

10. Dona, B.G., Scholz, U., Schwarzer, R., \& Sud, S. (2002). Is perceived Self-efficacy a universal construct, European Journal of personality and Social Psychology

11. Faure, S. \& Loxton, H. (2003). Anxiety, depression and self-efficacy levels of women undergoing first trimester abortion. South African Journal of Psychology, 33, 28-38.

12. Jahoda, M. (1958). Current concepts of positive mental health. New York: Basic Books 9.

13. Kashdan, T. B.\& Roberts, J. E. (2004).Social anxiety's impact on affect, curiosity, and social self-efficacy during a high self-focus social threat situation. Cognitive Therapy and Research, 28, 119-141.

14. Kashdan, T.B., Biswas-Diener, R., \& King, L. (2008). Reconsidering happiness: the costs of distinguishing between hedonics and eudaimonia. Journal of Positive Psychology 3, 219-233.

15. Keyes, C. L. M., \& Ryff, C. D. (1998). Generativity in adult lives: Social structural contours and quality of life consequences. In D. P. McAdams \& E. de St. Aubin (Eds.), Generativity and adult development: How and why we care for the next generation (pp. 227-263). Washington, D.C.: American Psychological Association.

16. Keyes, C.L.M., Ryff, C.D., \& Shmotkin, D. (2002). Optimizing well-being: the empirical encounter of two traditions. Journal of Personality and Social Psychology, 82 (6), 10071022.

17. Khramtsova, I., Sarrino, D.A., Gordeeva, T., \& Williams K. (2007). Happiness, life satisfaction, and depression in college students: Relations with student behaviors and attitudes. American Journal of Psychological Research, 3 (1), 8-16.

18. Luszczynska, A., \& Schwarzer, R. (2005). Social cognitive theory. In M. Conner \& P. Norman (Eds.), Predicting health behaviour (2nd ed. rev., pp. 127-169). Buckingham, England: Open University Press.

19. Lyubomirsky, S. (2001). Why are some people happier than others?: The role of cognition and motivational processes in well-being. American Psychologist, 56, 239-249.

20. Marmot, M. G., Fuhrer, R., Ettner, S. L., Marks, N. F., Bumpass, L. L., \& Ryff, C. D. (1998). Contribution of psychosocial factors to socioeconomic differences in health. Milbank Quarterly, 76 (3), 403-448.

21. Pajares, F., \& Schunk, D. H. ( 2001 ). self-beliefs and school success: self-efficasy, selfconcept, and school

22. Ormrod, J. E. (2006). Educational psychology: Developing learners (5th ed.). Upper Saddle River, N.J.: Pearson Merrill Prentice Hall.

23. Ozer, E. M., \& Bandura, A. (1990). Mechanisms governing empowerment effects: A self- efficacy analysis. Journal of Personality and Social Psychology, 58 (3), $472-486$ 
24. Ryff, C.D. (1989). Happiness is everything, or is it? Explorations on the meaning of psychological well-being. Journal of Personality and Social Psychology, 57 (6), 10691081.

25. Ryff, C.D., \& Keyes, C. (1995). The structure of psychological well-being revisited. Journal of Personality and Social Psychology, 69, 719-727.

26. Ryff, C.D., \& Singer, B. (1996). Psychological well-being: Meaning, measurement, and implications for psychotherapy research. Psychotherapy and Psychosomatics, 65, 14-23.

27. Sastre,M., \& Ferriere, G., (2000). Family decline and the subjective well-being of adolescents. Social Indicators Research, 49, 69-82.

28. Shek, D., (1997). The relation of the family functioning to adolescent psychological wellbeing, School adjustment and problem behavior. The Journal of Genetic Psychology, $158,467-479$.

29. Shnek, Z. M., Irvine, J., Stewart, D. \& Abbey, S. (2001). Psychological factors and depressive symptoms in ischemic heart disease. Health Psychology, 20, 141-145.

30. Salami, S.O., \& Ogundokun, M.O. (2009). Emotional intelligence and self-efficacy as predictors of academic performance. Perspectives in Education, 25 (3), 175-185.

31. VanWel, F., \& Linssen, A., \& Abma, R., (2000). The parental bond and the well-being adolescents and young adults. Journal of Youth and Adolescents, 29, 307-318.

32. Watson, D., Clark, L. A., \& Tellegen, A. (1988). Development and validation of brief measures of positive and negative affect: The PANAS scales. Journal of Personality and Social Psychology, 54 (6), 1063-1070.

33. Zimmerman, B.J.(2000). Attainment of self-regulation: A social cognitive perspective. In M.boekaerts, P.R. Pintrich, \& M. Zeidner (Eds.), Handbook of self-regulation (pp.13-39). San Deigo, CA: Academic Press.

34. Zimmerman, B. J., Bandura, A., \& Martinez-Pons, M.. (1992). Self-motivation for academic attainment: The role of self-efficacy beliefs and personal goal setting. American Educational Research Journal, 29, 663 